УДК 577.13:582.711.71

\title{
СОСТАВ И СОДЕРЖАНИЕ ФЛАВОНОИДОВ PЕNTAPHYLLOIDES FRUTICOSA В ПРИРОДЕ И КУЛЬТУРЕ
}

\author{
() Е.П. Храмова
}

\author{
Центральный Сибирский ботанический сад Сибирского отделения \\ Российской академии наук, ул. Золотодолинская, 101, Новосибирск, 630090 \\ (Россия), e-mail:khramova@ngs.ru
}

\begin{abstract}
Сравнительный анализ образцов Pentaphylloides fruticosa из природных и интродукционных популяций показал, что состав флавоноидного комплекса листьев, цветков и стеблей одинаков. Общее содержание флавоноидов в 6-летних растениях в условиях культуры ниже в 1,3-1,5 раза по сравнению с природной популяцией, из семян которой они были выращены. Изменения в накоплении флавоноидов в растениях P. fruticosa в культуре более заметны в условиях г. Новосибирска по сравнению с Центральным Алтаем (п. Камлак, Шебалинский р-н, Республика Алтай). Содержание компонента 3 , гиперозида, изокверцитрина, рутина и авикулярина преобладало в цветках по сравнению с листьями вне зависимости от условий произрастания. Компонент 10, кверцетин и кемпферол, напротив, превалировал в листьях.
\end{abstract}

Ключевые слова: Pentaphylloides fruticosa (пятилистник кустарниковый), флавоноиды, природная и интродукционная популяции.

\section{Введение}

В последние годы пятилистник кустарниковый, или курильский чай кустарниковый Pentaphylloides fruticosa (L.) O.Schwarz (Rosaceae) привлекает внимание фармакологов как лекарственное растение. Определены фармакогностические характеристики сырья P. fruticosa для стандартизации [1]. Установлен выраженный антимикробный эффект водного экстракта в отношении широкого спектра микроорганизмов [2-4]. Выявлена его противовирусная и иммуностимулирующая активность [5-8], антидиабетическое действие [9]. Установлена эффективность использования P. fruticosa в качестве природного адаптогена для профилактики дизадаптационных состояний [10].

Пятилистник кустарниковый разрешен к применению в пищевой промышленности. Используется как чай, нативный и ферментированный, под названием «Сибирский чай». Разработаны способы получения заменителя традиционного чая из растительного сырья пятилистника кустарникового [11-12]. P. fruticosa входит в состав безалкогольного многокомпонентного бальзама «Радиопротекторный», который рекомендуется для профилактики негативного воздействия окружающей среды, в том числе ионизирующего излучения [13].

В значительной степени ценность $P$. fruticosa для медицины и фармакологии обусловливается содержанием в нем биологически активных веществ с разносторонним действием и, в частности, флавоноидов.

Известно, что P. fruticosa относится к растениям, продуцирующим значительное количество флавоноидов, в основном флавонолов, содержание которых варьирует от $0,7 \%$ до $6,0 \%[1,4,14,15]$. Из надземной части пятилистника кустарникового выделены и идентифицированы агликоны - кверцетин, кемпферол и 7,3',4'-три-О-метилкверцетин, не менее 10 флавонолгликозидов - кверцетин-3- $\beta$-глюкопиранозид (изокверцитрин), кверцетин-3- $\beta$-галактопиранозид (гиперозид), кверцетин-3- $\beta$-рутинозид (рутин), кверцетин-3$\alpha$-рамнопиранозид (кверцитрин), кверцетин-3- $\alpha$-арабинофуранозид (авикулярин), кемпферол-3- $\beta$-рути-

Храмова Елена Петровна - старший научный сотрудник лаборатории фитохимии, кандидат биологических наук, тел.: (383) 339-98-17, e-mail: khramova@ngs.ru нозид, рамнетин-3- $\beta$-глюкопиранозид, рамнетин-3- $\beta$ галактопиранозид, рамнетин-3- $\alpha$-арабинофуранозид, кемпферол-3- $\beta$-глюкозид (астрагалин) и четыре аци- 
лированных флавонолгликозида - 6"-О-галлат-3- $\beta$-D-галактопиранозид кверцетина, кемпферол-3-O- $\beta$ (6"-О-(Е)-р-кумарил)-глюкопиранозид, тернифлорин и трибулозид [16-23].

Для расширения сырьевой базы в Республике Алтай пятилистник кустарниковый успешно выращивают в интродукционном питомнике Алтайского филиала ЦСБС СО РАН (с. Камлак, Шебалинский р-н, Республика Алтай). При интродукции растений неотьемлемой составной частью является изучение биохимического состава растений.

Цель работы заключалась в сравнительном изучении состава и содержания флавоноидов (в сумме, по группам и индивидуальным компонентам) в надземной части дикорастущих и выращенных в условиях культуры растений пятилистника кустарникового.

\section{Экспериментальная часть}

В качестве объектов исследования использовали растения (исходный материал) из окрестностей с. Бичикту-Бом (Онгудайский район, Республика Алтай) и выращенные на экспериментальном участке АФ ЦСБС (с. Камлак, Шебалинский р-н, Республика Алтай) из семян исходного материала 1996 и 2000 гг. сбора. Для сравнительного анализа в 2006 г. взяты образцы шестилетних растений, высаженных трехлетними саженцами в 2003 г. на экспериментальном участке ЦСБС СО РАН (Новосибирск). Саженцы выращены на интродукционном участке АФ ЦСБС СО РАН (с. Камлак) из семян природной ценопопуляции.

Для определения содержания флавоноидов (суммарного содержания, по группам и отдельным компонентам) брали среднюю пробу с 30-ти особей из природной популяции и интродукционных участков ЦСБС СО РАН (Новосибирск) и АФ ЦСБС СО РАН (с. Камлак) в фазу цветения (17 июля 2002 г. и 29 июня 2006 г.). Годичные облиственные побеги длиной 15-20 см срезали равномерно по поверхности кроны, разделяли на листья, стебли и цветки. Точную навеску свежесобранного растительного материала $(0,5$ г) заливали 96\% этанолом, настаивали 20-30 дней, затем исчерпывающе экстрагировали 70 и $96 \%$ этанолом при нагревании на водяной бане при $\mathrm{T}=60-70{ }^{\circ} \mathrm{C}[24]$.

Анализ флавоноидов пятилистника кустарникового выполняли методом высокоэффективной жидкостной хроматографии (ВЭЖХ) на жидкостном хроматографе Agilent 1100 (Agilent Technologies, США) с УФ-спектрофотометрическим детектором и программным обеспечением обработки хроматографических данных ChemStation. Подробное описание методики пробоподготовки, анализа и расчетов приведено нами ранее [25].

Разница в основных климатических показателях Центрального Алтая и Новосибирской области достаточно велика. Среднегодовая температура в районе естественного произрастания равна $-2,96{ }^{\circ} \mathrm{C}$, сумма температур за период со средней суточной температурой выше $10^{\circ} \mathrm{C}$ составляет $1200-1300{ }^{\circ} \mathrm{C}$, годовая сумма осадков 400-500 мм. На территории Алтайского филиала ЦСБС среднегодовая температура колеблется от +2 до $+3{ }^{\circ} \mathrm{C}$, сумма положительных температур выше $10^{\circ} \mathrm{C}$ равняется $1900{ }^{\circ} \mathrm{C}$, общее годовое количество осадков 500-700 мм. В ЦСБС (Новосибирск) среднегодовая температура составляет $+0,2{ }^{\circ} \mathrm{C}$, сумма температур выше $10^{\circ} \mathrm{C}-1920^{\circ} \mathrm{C}$, годовое количество осадков - 425 мм [26-27].

Район естественного произрастания $P$. fruticosa имеет высоту 900 м над ур.м., что в 1,4-5,3 раза выше по сравнению с интродукционными участками в с. Камлак (650 м) и в Новосибирске (169 м). В Центральном Алтае, в отличие от Новосибирской области, отмечается обилие солнечного сияния. В районе естественного произрастания среднемесячная инсоляция на горизонтальной поверхности за год по средним многолетним данным равна $3,65 \mathrm{\kappa BT} / \mathrm{m}^{2} /$ день, в районе алтайского интродукционного питомника $3,46 \mathrm{\kappa BT} / \mathrm{M}^{2} /$ день, в Новосибирской обл. - $3.18 \mathrm{\kappa BT} / \mathrm{m}^{2} /$ день [28]. Таким образом, район естественного произрастания отличается от районов интродукции более суровым климатом и обилием солнечного сияния, интродукционный участок АФ ЦСБС отличается от двух других по тепло- и влагообеспеченности.

\section{Обсуждение результатов}

Исследование флавоноидного состава методом ВЭЖХ показало, что в водно-этанольных экстрактах надземных органов пятилистника кустарникового, произрастающего в естественных местообитаниях и в условиях культуры, содержится не менее 14 соединений (рис. 1). 


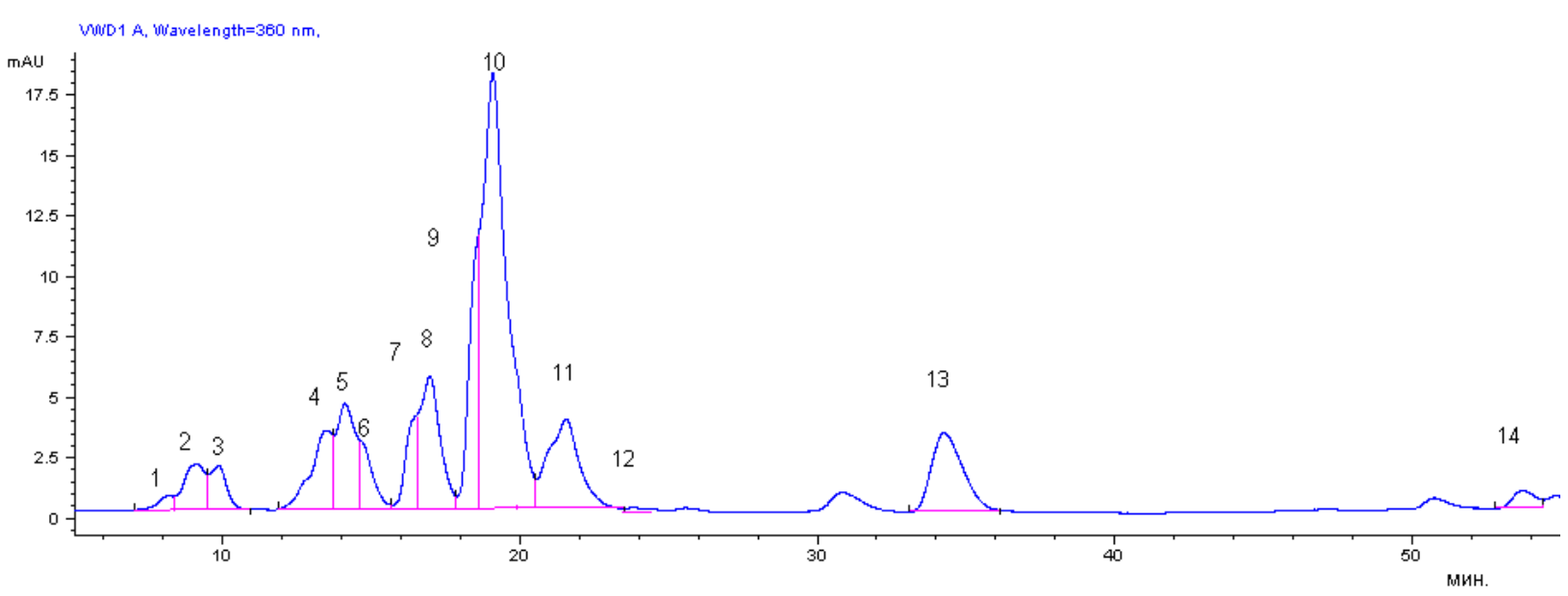

Рис. 1. Хроматограмма экстракта листьев 6-летних растений Pentaphylloides fruticosa, выращенных в интродукционном питомнике АФ ЦСБС (с. Камлак, Шебалинский район, Республика Алтай): 4 - гиперозид $\left(\mathrm{t}_{\mathrm{R}}=13,45\right.$ мин), 5 - изокверцитрин $\left(\mathrm{t}_{\mathrm{R}}=14,08\right.$ мин $), 6$ - рутин $\left(\mathrm{t}_{\mathrm{R}}=14,45\right.$ мин, 7 - эллаговая кислота $\left(\mathrm{t}_{\mathrm{R}}=16,56\right.$ мин $), 8$ - гликозид эллаговой кислоты $\left(\mathrm{t}_{\mathrm{R}}=16,94\right.$ мин $), 9-$ авикулярин $\left(\mathrm{t}_{\mathrm{R}}=18,77\right.$ мин $)$, 12 - кверцитрин ( $t_{R}=21,51$ мин), 13 - астрагалин $\left(t_{R}=23,81\right.$ мин), 14 - кверцетин $\left(t_{R}=34,24\right.$ мин), 15 - кемпферол $\left(\mathrm{t}_{\mathrm{R}}=53,69\right.$ мин $), 1-3,10$ - неидентифицированные компоненты. По оси абсцисс - время удерживания, мин, по оси ординат - оптическая плотность

На основании полученных спектральных данных (УФ- и масс-спектроскопии) и сопоставлении времен удерживания пиков веществ на хроматограммах анализируемых образцов с временами удерживания пиков стандартных образцов установлены шесть флавонолгликозидов - гиперозид, изокверцитрин, рутин, авикулярин, кверцитрин и астрагалин, два агликона - кверцетин и кемпферол, а также эллаговая кислота и ее гликозид. Изокверцитрин и астрагалин были выделены нами ранее из исследуемого растения, идентифицированы по результатам хроматографического анализа, данным спектроскопии УФ и ЯМР ${ }^{1} \mathrm{H}$ и ${ }^{13} \mathrm{C}[21]$ и использованы в данной работе в качестве стандартов. Остальные компоненты $(1-3,10)$ пока не идентифицированы, но в процессе хроматографирования в режиме «on-line» были зарегистрированы УФ-спектры некоторых из них. Для неидентифицированных компонентов характерно поглощение в УФ-видимой области спектра, при этом спектр поглощения содержит две полосы, одна из которых находится в низковолновой (250-290 нм) части (полоса II), другая — в более длинноволновой (340-380 нм) (полоса I). На основании этих данных все компоненты отнесены к флавоноидным структурам.

При сравнении хроматограмм экстрактов исследуемых образцов выявлено, что качественный состав флавоноидного комплекса дикорастущих и интродуцированных растений пятилистника кустарникового не изменился.

Содержание общей суммы флавоноидов в листьях дикорастущих растений и выращенных в питомнике АФ ЦСБС практически одинаково (29,66-32,63 мг/г от абс. сух. массы). Отличия составляют не более 7-10\%, что не превышает уровня их индивидуальной изменчивости внутри каждой выборки (рис. 2). Однако в листьях растений, выращенных на участке ЦСБС в Новосибирске, отмечалось снижение общего содержания флавоноидов до 21,38 мг/г, что на 40-50\% меньше по сравнению с дикорастущими особями и культивируемыми в алтайском интродукционном питомнике.

Анализ флавонолгликозидов показал преимущественное накопление гликозидов кверцетина по сравнению с гликозидами кемпферола во всех образцах вне зависимости от условий произрастания. Наибольшее содержание гликозидов кверцетина (26,42 мг/г) обнаружено в листьях двухлетних растений, выращенных на участке в АФ ЦСБС (с. Камлак), гликозидов кемпферола — в природных образцах (2,73 мг/г). В листьях шестилетних растений накапливалось на 17 и 39\% меньше гликозидов кверцетина и кемпферола соответственно по сравнению с двухлетними особями, что, по-видимому, объясняется возрастными отличиями, которые выражаются в бо́льшем накоплении флавонолов у более молодых растений. Наиболее заметная разница наблюдалась в содержании агликонов у дикорастущих и интродуцированных растений. В листьях растений, собранных на участке ЦСБС (Новосибирск), содержание агликонов ниже в 8 раз по сравнению с природными образцами и в 4-4,5 раза по сравнению с культивируемыми на Алтае (рис. 2). 


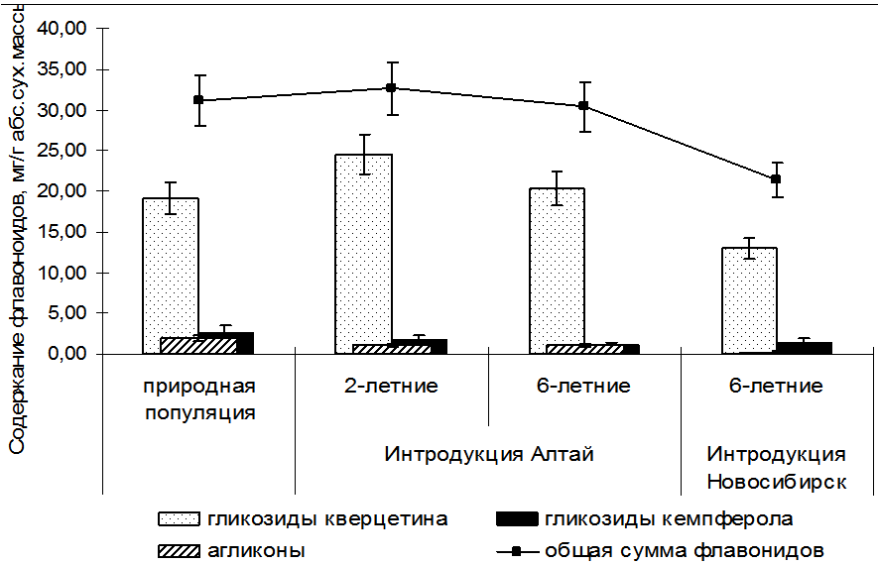

Анализ накопления индивидуальных компонентов показал, что в листьях растений из природы содержится максимальное количество рутина (9,56 мг/Г), изокверцитрина $(4,64$ мг/г), эллаговой кислоты (3,05 мг/г), ее гликозида (2,74 мг/г), компонента 2 (1,86 мг/г) и кверцетина $(1,74$ мг/г). Однако в отличие от интродуцированных растений накопление авикулярина и компонента 10 в листьях дикорастущих особей минимально. В молодых двухлетних растениях превалирует содержание компонентов 1 и 3, гиперозида, изокверцитрина, рутина и кверцитрина в 1,3-5 раз по сравнению с шестилетними особями (табл. 1). Содержание гиперозида, изокверцитрина, рутина, гликозида эллаговой кислоты, кверцетина и кемпферола у новосибирских экземпляров меньше по сравнению с природными растениями и выращенными из семян на экспериментальном участке в Горном Алтае. По-видимому, это объясняется условиями культуры в Новосибирске, в которых не реализуются потенциальные возможности вида к более высокому накоплению флавоноидов.

Из полученных результатов следует, что уровень содержания флавоноидов в листьях P. fruticosa, произрастающих в природе и выращенных в культуре в Горном Алтае, выше на 40-50\% по сравнению с растениями, выращенными в Новосибирске. Это хорошо согласуется с условиями произрастания растений - повышенным уровнем притока солнечной радиации на Алтае и высотой произрастания над уровнем моря. Как отмечает С.П. Хромов [29], высота также является географическим фактором климата, поскольку атмосферное давление с повышением высоты падает, солнечная радиация и эффективное излучение возрастает, температура, как правило, убывает, влажность снижается, а ветер достаточно меняется по скорости и направлению. Хорошо известно, что метаболизм флавоноидов и их накопление зависит не только от экологических особенностей видов, но и факторов внешней среды. Разнообразные внешние воздействия, в частности, избыток УФ-радиации, гидротермический стресс и другое, индуцируют специфический фермент - фенилаланинаммиак-лиазу (ФАЛ), активация которого приводит к увеличению количества флавоноидов в клетках растений, защищая их от стрессового воздействия [30]. По мнению Chaves et al. [31], основным индуктором, повышающим секрецию флавоноидов у Cistus ladanifer в течение лета, является УФ-облучение, синергически дополненное засухой. Экспериментально показано, что эффект затенения отрицательно влияет на накопление флавонолов и особенно кверцетина [32], а температура не оказывает практически никакого влияния $[31,33]$. Это означает, что УФ-специфическая индукция синтеза флавоноидов может играть важную роль при повышении УФ-радиации [33-35].

Общее содержание в цветках P. fruticosa дикорастущей ценопопуляции на 60 \% выше по сравнению с листьями. В культуре цветки и листья накапливают практически одинаковое количество - 30,98 и 30,45 мг/г соответственно (табл. 2).

При этом наблюдается повышение суммы гликозидов на фоне снижения суммы агликонов в цветках интродуцированных растений в отличие от дикорастущих.

Содержание компонента 3 , гиперозида, изокверцитрина, рутина и авикулярина превалирует в цветках по сравнению с листьями вне зависимости от условий произрастания. Напротив, компонент 10, кверцетин и кемпферол преобладал в листьях по сравнению с цветками.

В побегах пятилистника кустарникового содержание флавоноидов значительно ниже, чем в листьях и цветках. Тем не менее прослеживается та же тенденция, что и для цветков. Побеги растений интродукционной популяции накапливают почти в 2 раза меньше флавоноидов, но при этом содержание гликозидов выше, чем в природной выборке (табл. 3). Агликоны превалируют в побегах дикорастущих особей. 
Таблица 1. Содержание компонентов в листьях Pentaphylloides fruticosa из природной популяции (окр. с. Бичикту-Бом) и интродукционных популяций (АФ ЦСБС, с. Камлак; ЦСБС, Новосибирск)

\begin{tabular}{l|c|c|c|c}
\hline \multirow{2}{*}{\multicolumn{1}{c|}{ Соединение }} & \multirow{2}{*}{$\begin{array}{c}\text { Природная } \\
\text { популяция }\end{array}$} & $\begin{array}{c}\text { Интродукционная популяция } \\
\text { (АФ ЦСБС, с. Камлак) }\end{array}$ & $\begin{array}{c}\text { Интродукционная популя- } \\
\text { ция (ЦСБС, Новосибирск) }\end{array}$ \\
\cline { 3 - 5 } & (окр. с. Бичикту-Бом) & 2-летние & 6 -летние & 6 -летние \\
\hline Компонент (1) & 1,67 & 1,71 & 0,33 & 0,86 \\
Компонент (2) & 1,86 & 0,98 & 1,04 & 0,58 \\
Компонент (3) & 1,08 & 1,52 & 0,79 & 0,96 \\
Гиперозид (4) & 1,52 & 2,75 & 1,88 & 1,12 \\
Изокверцитрин (5) & 4,64 & 2,96 & 2,02 & 1,01 \\
Рутин (6) & 9,56 & 2,11 & 1,09 & 0,20 \\
Эллаговая кислота (7) & 3,05 & 0,79 & 1,61 & 3,97 \\
Гликозид эллаговой кислоты (8) & 2,74 & 2,11 & 2,44 & 9,84 \\
Авикулярин (9) & 0,45 & 10,78 & 3,90 & 1,15 \\
Компонент 10 & 0,98 & 4,28 & 2,17 & 0,27 \\
Кверцитрин (11) & 0,13 & 0,20 & 0,94 & 0,16 \\
Астрагалин (12) & 0,11 & 0,94 & 0,87 & 0,08 \\
Кверцетин (13) & 1,74 & 0,14 & 0,13 & \\
Кемпферол (14) & 0,14 & & & \\
\hline
\end{tabular}

Таблица 2. Содержание флавоноидов в цветках Pentaphylloides fruticosa из природной популяции (окр. с. Бичикту-Бом) и интродукционной популяции (АФ ЦСБС, с. Камлак)

\begin{tabular}{l|c|c}
\hline \multicolumn{1}{c|}{ Соединение } & $\begin{array}{c}\text { Природная популяция } \\
\text { (окр. с. Бичикту-Бом) }\end{array}$ & $\begin{array}{c}\text { Интродукционная популяция (АФ } \\
\text { ЦСБС, с. Камлак) 6- летние растения }\end{array}$ \\
\hline Компонент (1) & 0,52 & 2,16 \\
Компонент (2) & 5,91 & 0,99 \\
Компонент (3) & 4,49 & 5,18 \\
Гиперозид (4) & 7,06 & 7,89 \\
Изокверцитрин (5) & 6,39 & 4,14 \\
Рутин (6) & 13,47 & 0,52 \\
Эллаговая кислота (7) & 2,51 & 1,60 \\
Гликозид эллаговой кислоты (8) & 4,88 & 4,76 \\
Авикулярин (9) & 1,00 & 1,40 \\
Компонент 10 & 0,39 & 0,28 \\
Кверцитрин (11) & 0,72 & 0,17 \\
Астрагалин (12) & 0,13 & 0,61 \\
Кверцетин (13) & 0,96 & 0,03 \\
Кемпферол (14) & 0,17 & 30,98 \\
Общая сумма флавоноидов & 48,61 & 5,79 \\
Из них: & & 1,80 \\
Гликозиды кверцетина & 3,33 & 0,64 \\
Гликозиды кемпферола & 0,23 & \\
Сумма агликонов & 1,13 & \\
\hline
\end{tabular}

Таблица 3. Содержание флавоноидов в побегах Pentaphylloides fruticosa из природной популяции (окр. с. Бичикту-Бом) и интродукционной популяции (АФ ЦСБС, с. Камлак)

\begin{tabular}{l|c|c}
\hline \multicolumn{1}{c|}{ Соединение } & $\begin{array}{c}\text { Природная популяция } \\
\text { (окр. с.Бичикту-Бом) }\end{array}$ & $\begin{array}{c}\text { Интродукционная популяция (АФ } \\
\text { ЦСБС, с. Камлак) 6-летние растения }\end{array}$ \\
\hline \multicolumn{1}{c|}{1} & 2 & 3 \\
\hline Компонент (1) & 0,28 & 0,15 \\
Компонент (2) & 0,30 & 0,22 \\
Компонент (3) & 0,09 & 0,08 \\
Гиперозид (4) & 0,12 & 0,17 \\
Изокверцитрин (5) & 1,64 & 0,63 \\
Рутин (6) & 4,05 & 0,93 \\
Эллаговая кислота (7) & 0,30 & 0,08 \\
Гликозид эллаговой к-ты (8) & 0,44 & 0,15 \\
Авикулярин (9) & 0,21 & 1,10 \\
Компонент 10 & 0,07 & 0,46 \\
Кверцитрин (11) & 0,05 & 0,03 \\
\hline
\end{tabular}


Окончание таблищь 3

\begin{tabular}{l|c|c}
\hline \multicolumn{1}{c|}{$\quad$ 1 } & 2 & 3 \\
\hline Астрагалин (12) & 0,05 & 0,04 \\
Кверцетин (13) & 0,15 & 0,10 \\
Кемпферол (14) & 0,01 & 0,01 \\
Общая сумма флавоноидов & 7,77 & 4,16 \\
Из них: & 0,09 & 0,13 \\
Гликозиды кверцетина & 0,17 & 0,32 \\
Гликозиды кемпферола & 0,26 & 0,45 \\
Сумма агликонов & 0,16 & 0,11 \\
\hline
\end{tabular}

В стеблях природных образцов наблюдается повышенное накопление изокверцитрина, рутина, эллаговой кислоты и ее гликозида, кверцетина по сравнению с растениями, выращенными в интродукционном питомнике АФ ЦСБС (с. Камлак).

В результате проведенного исследования установлено, что уровни содержания флавоноидов в листьях P. fruticosa, произрастающих в природе и выращенных в культуре в Горном Алтае, практически равнозначны, но выше на 40-50\% по сравнению с растениями, выращенными в Новосибирске. При этом отмечено, что листья растений из Новосибирска, тем не менее, накапливают значительное количество флавоноидов (до 21,38 мг/г от абс. сух. массы), что представляет несомненный интерес к этому растению как источнику флавоноидов.

\section{Выводы}

1. Сравнительный анализ образцов Pentaphylloides fruticosa из природных и интродукционных популяций показал, что качественный состав флавоноидного комплекса листьев, цветков и стеблей одинаков.

2. По общему количеству флавоноидов отмечалась разнокачественность надземных органов пятилистника кустарникового в природной популяции: минимальная концентрация флавоноидов обнаружена в стеблях, максимальная - в цветках. В культуре общее содержание флавоноидов в листьях и цветках равнозначно.

3. Общее содержание флавоноидов в 6-летних растениях в условиях культуры ниже в 1,3-1,5 раза по сравнению с природной популяцией, из семян которой они были выращены.

4. Содержание компонента 3, гиперозида, авикулярина, изокверцитрина и рутина преобладало в цветках по сравнению с листьями вне зависимости от условий произрастания. Компонент 10, кверцетин и кемпферол, напротив, превалировал в листьях.

5. Изменения в накоплении флавоноидов в растениях P. fruticosa в культуре более заметны в условиях Новосибирска по сравнению с Центральным Алтаем (п. Камлак, Шебалинский р-н, Республика Алтай).

\section{Список литературы}

1. Николаева И.Г., Хобракова В.Б., Арьяева М.М. Пятилистник кустарниковый (Курильский чай кустарниковый). Улан-Удэ, 2001. $110 \mathrm{c.}$

2. Макаренко Н.Г., Чайка В.М. Антимикробная активность представителей рода Potentilla L. Юго-Восточного Алтая в связи с их систематикой и экологией // Растительные ресурсы. 1974. Т. 10, вып. 2. С. 180-187.

3. Вичканова С.А., Адгина В.В., Изосимова С.Б., Фатеева Т.В. Изучение антимикробной активности растений рода Potentilla (сем. Rosaceae) // Новые лекарственные препараты из растений Сибири и Дальнего Востока : матер. Всесоюзной конф. Томск, 1986. С. 30-31.

4. Tomczyk M., Pleszczyńska M., Wiater A. Variation in Total Polyphenolics Contents of Aerial Parts of Potentilla Species and Their Anticariogenic Activity // Molecules. 2010. Vol. 15. Pp. 4639-4651.

5. Volkhonskaya T.A., Shkel N.M., Khramova E.P., Grek O.R., Evstropov A.N. Phenolic Compounds of Pentaphylloides fruticosa (L.) O.Schwarz and Their Antiviral and Immunostimulative Activities // International Conference on Natural Products and Physiologically Active Substances. Novosibirsk, 1998. P. 34.

6. Евстропов А.Н., Бурова Л.Г., Грек О.Р., Захарова Л.Н., Волхонская Т.А. Применение полифенольного комплекса, экстрагированного из пятилистника кустарникового (Penthaphylloides fruticosa (L.) O. Scwarz), для профилактики Коксаки-вирусной инфекции // Бюллетень сибирской медицины. 2002. №4. С. 27-31.

7. Патент 2072865 (РФ). Способ получения вещества, обладающего противовирусной и иммуностимулирующей активностью / О.Р. Грек, Т.А. Волхонская, В.М. Триль, С.Н. Письмерова, В.Е. Яворовская, А.Н. Евстропов, И.В. Аристов, Е.Р. Николин, О.П. Колесникова, В.А. Козлов. 10.02.1997. БИ. №4. 
8. Патент 2203080 РФ. А 61 К 35/78, А 61 Р 31/12. Способ получения водорастворимого фитоэкстракта, обладающего противовирусной активностью / Грек О.Р., Волхонская Т.А., Бурова Л.Г., Захарова Л.Н., Евстропов А.Н. (Россия). № 2001131660/14. Заявлено 22.11.2001; Опубл. 27.04.2003. Бюл. № 12.

9. Арьяева М.М. Влияние сухого экстракта курильского чая кустарникового на течение экспериментального сахарного диабета : автореф. дис.... канд. мед. наук. Улан-Удэ, 1998. 20 с.

10. Хышиктуев Б.С., Кузнецова Н.С., Цыденбаев П.Б. Коррекция гормонально-метаболических сдвигов у студентов младших курсов в процессе адаптации // Бюллетень ВСНЦ СО РАМН. 2008. №6(64). С. 16-20.

11. Патент 2053678 (РФ). Способ получения концентрата заменителя чая / Н.М. Шкель, В.М. Триль, Т.А. Волхонская, Е.П. Храмова. 10.02.1996. БИ №4.

12. Патент 2061383 (РФ). Способ получения заменителя чая / Шкель Н.М., Триль В.М., Волхонская Т.А. 10.06.1996. БИ. №16.

13. Высочина Г.И., Волхонская Т.А., Перфильева Л.В., Обухова Л.А., Кукушкина Т.А., Карпова Е.А. Безалкогольные лечебно-профилактические бальзамы на основе сибирских трав и ягод // Актуальные проблемы инноваций с нетрадиционными природными ресурсами и создания фундаментальных продуктов : матер. II Российской научнопракт. конфер. М., 2003. С. 266-267.

14. Триль В.М., Волхонская Т.А., Шкель Н.М. Особенности накопления БАВ в курильском чае кустарниковом в природе и культуре // Особенности акклиматизации многолетних интродуцентов, накапливающих биологически активные вещества: тез. докл. науно-практ. конфер. Краснодар, 1995. С. 239-242.

15. Храмова Е.П. Динамика содержания флавонолов в надземных органах Pentaphylloides fruticosa (L.) O.Schwarz различных экотипов, выращиваемых в Новосибирске // Растительные ресурсы. 1999. Вып. 4. С. 31-38.

16. Bate-Smith E.C. Chromatography and taxonomy in the Rosaceae with special reference to Potentilla and Prunus // J. Linnean Soc. London. 1961. Botany. Vol. 58, N370. Pp. 39-54.

17. Федосеева Г.М. Фенольные соединения Potentilla fruticosa // Химия природных соединений. 1979. №4. С. 575-576.

18. Растительные ресурсы СССР. Л., 1987. 326 с.

19. Ганенко Т.В., Луцкий В.И., Ларин М.Ф., Верещагин А.Л., Семенов А.А. Химический состав Potentilla fruticosa 1. Флавоноиды // Химия природных соединений. 1988. №3. С. 451.

20. Ганенко Т.В., Верещагин А.Л., Семенов А.А. Химический состав Potentilla fruticosa 3. Флавоноиды и свободные стерины // Химия природных соединений. 1991. №2. С. 285.

21. Шкель Н.М., Храмова Е.П., Кузаков Е.В., Волхонская Т.А., Триль В.М. Фенольные соединения Pentaphylloides fruticosa (L.) O. Schwarz // Химия в интересах устойчивого развития. 1997. Т. 5, №1. С. 123-127.

22. Miliauskas G., Beek T.A. van, Venskutonis P.R., Linssen, J.P.H., de Waard P., Sudhölter E.J. Antioxidant activity of Potentilla fruticosa // Journal of the Science of Food and Agriculture. 2004. Vol. 84. Pp. 1997-2009.

23. Растительные ресурсы России: Дикорастущие цветковые растения, их компонентный состав и биологическая активность. Т. 2. Семейства Actinidiaceae - Malvaceae, Euphorbiaceae - Haloragaceae / отв. ред. А.Л. Буданцев. СПб. ; М., 2009. 513 с.

24. Минаева В.Г. Лекарственные растения Сибири. Новосибирск, 1991. 277 с.

25. Храмова Е.П., Комаревцева Е.К. Изменчивость флавоноидного состава листьев Potentilla fruticosa (Rosaceae) разных возрастных состояний в условиях Горного Алтая // Растительные ресурсы. 2008. Т. 44, вып. 3. С. 96-102.

26. Агроклиматические ресурсы Новосибирской области. Л., 1971. 153 с.

27. Климат Новосибирска. Л., 1979. 223 с.

28. Метеостатистика. [Электронный ресурc]. URL: http://meteo-altai.ru/.

29. Хромов С.П. Метеорология и климатология для географических факультетов. Л., 1983. 456 с.

30. Запрометов М.Н. Фенольные соединения: Распространение, метаболизм и функции в растениях. М., 1993. 272 с.

31. Chaves N., Escuredo J.C., Gutierrez-Merino C. Role of ecological variables in the seasonal variation of flavonoid content of Cistus ladanifer exudate // Journal of Chemical Ecology. 1987. Vol. 23, N3. Pp. 579-603.

32. Spayd S., Tarara J., Mee D., Ferguson J. Separation of Sunlight and Temperature Effects on the Composition of Vitis vinifera cv. Merlot Berries.Am // J. Enol. Vitic. 2002. Vol. 53. Pp. 171-182.

33. Downey M.O., Harvey J.S., Robinson S.P. The effect of bunch shading on berry development and flavonoid accumulation in Shiraz grapes // Aust. J. Grape Wine Res. 2004. Vol. 10. Pp. 55-73

34. Израэль Ю.А., Кунина И.М., Семенов С.М. Экологические эффекты УФ-радиации в области Б на растительность суши // Проблемы экологического мониторинга и моделирования экосистем: труды совещ. СПб., 1986. T. XVI. C. 9-23.

35. Cortell J., Kennedy J.A. Effect of shading on accumulation of flavonoid compounds in (Vitis vinifera L.) Pinot Noir fruit and extraction in a model system // J. Agric. Food Chem., 2006. Vol. 54. Pp. 8510-8520. 


\section{Khramova E.P. THE CONTENT AND COMPOSITION OF FLAVONOIDS PENTAPHYLLOIDES FRUTICOSA IN NATURAL CONDITIONS AND THE INTRODUCTION}

Central siberian botanical garden Siberian Branch of Russian Academy of Sciences, Zolotodolinskaia st., 101, Novosibirsk, 630090 (Russia), e-mail: khramova@ngs.ru

The composition and content of flavonoid in the above-ground plant organs Pentaphylloides fruticosa (bush cinquefoil from Rosaceae family) in natural conditions and the introduction were studied. The samples for the study were picked in natural cenopopulation (Central Altai, Ongudai District, near the village Bichiktu-Bom) and at the introduction division of the Altai branch CSBG (Central Altai, Shebalinsk District, village Kamlak) and CSBG (city Novosibirsk) in July 2002 and 2006 during full blossom. The plants were grown from the seeds gathered in 1996 and 2000 in natural cenopopulation (Central Altai, Ongudai District, near the village Bichiktu-Bom). Identification and the quantitative content of flavonoids were performed by high-performance liquid chromatography (HPLC). It has been established, that the composition of flavonoid of leaves, flowers and annual shoots not changed. The total flavonoid content in the 6 year old plants in the introduction was 1,3-1,5 times lower in comparison with natural cenopopulations of the seeds which they were grown. Changes in the accumulation of flavonoids in $P$. fruticosa cultivated in the plot of introduction in CSBG (Novosibirsk) more visible, compared with the Central Altai (village Kamlak). The component 3, Hyperoside, Isoquercitrin, Quercetin-3- $\beta$-rutinoside, and Quercetin-3- $\alpha$-arabinofuranoside higher in the flowers than in the leaves, regardless of the growth conditions. The component 10, Quercetin and Kaempferol, however, prevailed in the leaves.

Keywords: Pentaphylloides fruticosa (bush cinquefoil), flavonoids, natural cenopopulation, introduction

\section{References}

1. Nikolaeva I.G., Khobrakova V.B., Ar'iaeva M.M. Piatilistnik kustarnikovyi (Kuril'skii chai kustarnikovyi). [Shrubby cinquefoil (Kuril tea shrub).] Ulan-Ude, 2001, 110 p. (in Russ.).

2. Makarenko N.G., Chaika V.M. Rastitel'nye resursy, 1974, vol. 10, no. 2, pp. 180-187. (in Russ.).

3. Vichkanova S.A., Adgina V.V., Izosimova S.B., Fateeva T.V. Novye lekarstvennye preparaty iz rastenii Sibiri i Dal'nego Vostoka: mater. vsesoiuznoi konf. [New drugs from plants in Siberia and the Far East: Materials of All-Union Conference]. Tomsk, 1986, pp. 30-31. (in Russ.).

4. Tomczyk M., Pleszczyńska M., Wiater A. Molecules, 2010, vol. 15, pp. 4639-4651.

5. Volkhonskaya T.A., Shkel N.M., Khramova E.P., Grek O.R., Evstropov A.N. International Conference on Natural Products and Physiologically Active Substances, Novosibirsk, 1998, p. 34.

6. Evstropov A.N., Burova L.G., Grek O.R., Zakharova L.N., Volkhonskaia T.A. Biulleten'sibirskoi meditsiny, 2002, no. 4, pp. 27-31. (in Russ.).

7. Patent 2072865 (RU). 1997. (in Russ.).

8. Patent 2203080 (RU). 2003. (in Russ.).

9. Ar'iaeva M.M. Vliianie sukhogo ekstrakta kuril'skogo chaia kustarnikovogo na techenie eksperimental'nogo sakharnogo diabeta : avtoref. dis... kand. med. nauk. [Effect of dry extract shrubby cinquefoil shrub on experimental diabetes: the dissertation of Medical Sciences.]. Ulan-Ude, 1998. 20 p. (in Russ.).

10. Khyshiktuev B.S., Kuznetsova N.S., Tsydenbaev P.B. Biulleten' VSNTs SO RAMN, 2008, no. 6(64), pp. 16-20. (in Russ.).

11. Patent 2053678 (RU). 1996. (in Russ.).

12. Patent 2061383 (RU). 1996. (in Russ.).

13. Vysochina G.I., Volkhonskaia T.A., Perfil'eva L.V., Obukhova L.A., Kukushkina T.A., Karpova E.A. Aktual'nye problemy innovatsii s netraditsionnymi prirodnymi resursami i sozdaniia fundamental'nykh produktov: mater. II rossiiskoi nauchnoprakt. konfer. [Actual problems of innovation in unconventional natural resources and the creation of basic products: Materials II Russian scientific-practical conference]. Moscow, 2003, pp. 266-267. (in Russ.).

14. Tril' V.M., Volkhonskaia T.A., Shkel' N.M. Osobennosti akklimatizatsii mnogoletnikh introdutsentov, nakapli-vaiushchikh biologicheski aktivnye veshchestva. tez. dokl. nauchno-prakt. konfer. [Features multi-acclimatization of exotic species that accumulate biologically active substances. Abstracts of scientific conference]. Krasnodar, 1995, pp. 239-242. (in Russ.).

15. Khramova E.P. Rastitel'nye resursy, 1999, no. 4, pp. 31-38. (in Russ.).

16. Bate-Smith E.C. J. Linnean Soc. London, 1961, Botany, vol. 58, no. 370, pp. 39-54.

17. Fedoseeva G.M. Khimiia prirodnykh soedinenii, 1979, no. 4, pp. 575-576. (in Russ.).

18. Rastitel'nye resursy SSSR. [Plant Resources of the USSR]. Leningrad, 1987, 326 p. (in Russ.).

19. Ganenko T.V., Lutskii V.I., Larin M.F., Vereshchagin A.L., Semenov A.A. Khimiia prirodnykh soedinenii, 1988, no. 3, p. 451. (in Russ.).

20. Ganenko T.V., Vereshchagin A.L., Semenov A.A. Khimiia prirodnykh soedinenii, 1991, no. 2, p. 285. (in Russ.).

21. Shkel' N. M, Khramova E.P., Kuzakov E.V., Volkhonskaia T.A., Tril' V.M. Khimiia v interesakh ustoichivogo razvitiia, 1997, vol. 5, no. 1, pp. 123-127. (in Russ.).

22. Miliauskas G., van Beek T.A., Venskutonis P.R., Linssen, J.P.H., de Waard P., Sudhölter E.J. Journal of the Science of Food and Agriculture, 2004, vol. 84, pp. 1997-2009.

23. Rastitel'nye resursy Rossii: Dikorastushchie tsvetkovye rasteniia, ikh komponentnyi sostav i biologicheskaia aktivnost'. T. 2. Semeistva Actinidiaceae - Malvaceae, Euphorbiaceae - Haloragaceae. [Plant Resources of Russia: Wild flowering plants, their component structure and biological activity. Vol. 2. Family Actinidiaceae - Malvaceae, Euphorbiaceae Haloragaceae.]. Ed. A.L. Budantsev. St. Petersburg; Moscow, 2009, 513 p. (in Russ.).

24. Minaeva V.G. Lekarstvennye rasteniia Sibiri. [Medicinal Plants of Siberia.]. Novosibirsk, 1991, 277 p. (in Russ.).

25. Khramova E.P., Komarevtseva E.K. Rastitel'nye resursy, 2008, vol. 44, no. 3, pp. 96-102. (in Russ.). 
26. Agroklimaticheskie resursy Novosibirskoi oblasti. [Agroclimatic resources of the Novosibirsk Region.]. Leningrad, 1971, 153 p. (in Russ.).

27. Klimat Novosibirska. [Climate Novosibirsk.]. Leningrad, 1979, 223 p. (in Russ.).

28. Meteostatistika. [Meteostatistics.]. URL: http://meteo-altai.ru/. (in Russ.).

29. Khromov S.P. Meteorologiia i klimatologiia dlia geograficheskikh fakul'tetov. [Meteorology and climatology for geography departments.]. Leningrad, 1983, 456 p. (in Russ.).

30. Zaprometov M.N. Fenol'nye soedineniia: Rasprostranenie, metabolizm i funktsii v rasteniiakh. [Phenolic compounds: Distribution, metabolism and function in plants.]. Moscow, 1993, 272 p. (in Russ.).

31. Chaves N., Escuredo J.C., Gutierrez-Merino C. Journal of Chemical Ecology, 1987, vol. 23, no. 3, pp. 579-603.

32. Spayd S., Tarara J., Mee D., Ferguson J. J. Enol. Vitic., 2002, vol. 53, pp. 171-182.

33. Downey M.O., Harvey J. S., Robinson S.P. Aust. J. Grape Wine Res., 2004, vol. 10, pp. 55-73

34. Izrael' Iu.A., Kunina I.M., Semenov S.M. Problemy ekologicheskogo monitoringa i modelirovaniia ekosistem: trudy soveshch. [Problems of ecological monitoring and modeling of ecosystems: proceedings of the meeting.]. St. Petersburg, 1986, vol. XVI, pp. 9-23. (in Russ.).

35. Cortell J., Kennedy J.A. J. Agric. Food Chem., 2006, vol. 54, pp. 8510-8520.

Received February 2, 2013 
